\title{
Pengaruh Intensitas Pengunaan Gadget dan Keikutsertaan TPA Terhadap Kemampuan Membaca Al-Quran
}

\author{
Khoirul Anisa $^{1}$, Retno Wahyuningsih ${ }^{2}$ \\ ${ }^{1,2}$ IAIN SURAKARTA \\ *khoirul4nis4@gmail.com
}

\begin{abstract}
This study aims to determine (1) the effect of the intensity of using gadget on the ability recite Qur'an, (2) the effect of TPA participation on the ability recite Qur'an, (3) the effect of the intensity of using gadget and TPA participation on the ability recite Qur'an. The study was conducted in 2020. The population is fifth grade students of SD Negeri Cluster II Ahmad Yani Laweyan Surakarta on academic years of 2020/2021. The samples were drawn randomly from the population using a stratified random sampling technique. The study used experimental methods. The data were analyzed using two - way analysis of variance and further test of data processing with software SPSS 22 For Windows. The results showed that the highest average score was students who had low intensity of using gadget and participated in TPA (89.467) and the lowest score was students who had low intensity of using gadget and did not attend TPA (58.5). This proves that the higher the use of gadget $s$ and the more active students are in participating in the TPA, the higher the ability recite Qur'an. So, it can be concluded (1) The intensity of using gadget did not affect the students' ability to read AlQuran, (2) TPA participation affected the ability recite Qur'an, (3) The intensity of using gadget and TPA participation affected the ability recite Al-Quran.
\end{abstract}

Keywords: gadget, participation, ability

\begin{abstract}
ABSTRAK
Penelitian ini bertujuan untuk mengetahui (1) pengaruh intensitas penggunaan gadget terhadap kemampuan membaca Al-Quran, (2) pengaruh keikutsertaan TPA terhadap kemampuan membaca AlQuran, (3) pengaruh intensitas penggunaan gadget dan keikutsertaan TPA terhadap kemampuan membaca Al-Quran. Penelitian dilakukan pada tahun 2020. Populasi adalah peserta didik kelas V SD Negeri Gugus II Ahmad Yani Laweyan Surakarta tahun ajaran 2020/2021. Sampel ditarik secara random dari populasi menggunakan teknik sampling acak berstrata. Penelitian menggunakan metode eksperimen. Data dianalisis menggunakan analisis varians dua jalan dan uji lanjut pengolahan data dengan perangkat lunak SPSS 22 For Windows. Hasil penelitian menunjukkan bahwa nilai rata-rata tertinggi adalah peserta didik yang memiliki intensitas penggunaan gadget rendah dan mengikuti TPA $(89,467)$ dan nilai yang terendah adalah peserta didik yang intensitas penggunaan gadget rendah dan tidak mengikuti TPA $(58,5)$. Hal ini membuktikan bahwa semakin tinggi penggunaan gadget dan semakin keaktifan peserta didik mengikuti TPA maka kemampuan membaca Al-Qur'an akan semakin tinggi. Jadi, dapat disimpulkan bahwa (1) Intensitas penggunaan gadget tidak berpengaruh terhadap kemampuan membaca Al-Quran peserta didik, (2) Keikutsertaan TPA berpengaruh terhadap kemampuan membaca Al-Quran, (3) Intensitas penggunaan gadget dan keikutsertaan TPA berpengaruh terhadap kemampuan membaca Al-Quran.
\end{abstract}

Kata kunci : gadget, keikutsertaan, kemampuan 


\section{PENDAHULUAN}

Al-Qur'an dapat memberikan ketenangan jiwa bagi yang membacanya, dan inilah yang menunjukkan bahwa Al-Qur'an merupakan obat penyakit yang ada di dalam diri umat Islam. Mempelajari Al-Qur'an adalah merupakan perintah dari ajaran Islam. Keterampilan membaca pada umumnya diperoleh dengan cara mempelajarinya di sekolah sebagai pendidikan formal walaupun faktor-faktor pendukung khususnya kemampuan membaca Al-Qur'an berawal dari pendidikan non formal maupun informal.

Keberhasilan dalam pembelajaran Al-Qur'an tidak cukup hanya diberikan di sekolah saja, akan tetapi orang tua dan masyarakat juga berperan dalam pendidikan tersebut. Pendidikan dalam lingkungan keluarga memiliki peranan yang sanggat penting, ini karena setiap individu mendapatkan pendidikan yang pertama dalam keluarga. Pada dasarnya kurangnya perhatian orang tua terhadap kemampuan membaca Al-Qur'an peserta didik serta lingkungan masyarakat yang gemar bermain sehingga kurangnya mendukung dan pengaruh penggunaan gadget menjadikan salah satunya peserta didik kurang mampu membaca Al-Qur'an.

Guru Mata Pelajaran PAI SDN Jajar II Surakarta melakukan penelitian pada tanggal 17 September 2020 pada kelas V mendapatkan permasalahan yang terjadi pada pembelajaran PAI di sekolah dasar negeri yaitu peserta didik kurang memahami makhrojul huruf dan membaca yang kurang lancar mejadikan kurangnya kemampuan membaca AlQur'an peserta didik yang sanggat berpengaruh terhadap proses pembelajaran PAI di sekolah yang sudah banyak menuntut peserta didik untuk mampu membaca Al-Qur'an sekaligus mengartikannya.

Hasil wawancara dengan Guru mata pelajaran PAI di SD Negeri Gugus II Ahmad Yani Laweyan Surakarta menjelaskan bahwa kemampuan membaca Al-Qur'an pada peserta didik kelas V mereka di uji satu persatu maju kedepan guru PAI untuk membaca Al-Qur'an yang sudah disediakan oleh guru. Harapan dari guru PAI tentunya peserta didik dapat mengenal huruf hijaiyah serta dapat membaca Al-Qur'an. Ternyata hasilnya kurang seperti yang diharapkan, bahwa rata ratanya rendah. Bahkan ada juga peserta didik yang belum bisa membaca huruf hijaiyah dan membedakannya.

Hasil wawancara dari salah satu wali murid mengeluhkan anaknya malas untuk belajar membaca Al-Quran dikarenakan seringnya peserta didik mengunakan gadget terutama banyaknya game yang menarik dan bermain yang terlalu lama menjadikan peserta didik malas untuk membaca Al-Quran, permasalahan ini terjadi pada beberapa peserta didik SD Negeri Gugus II Ahmad Yani Laweyan Surakarta. Peserta didik lebih 
memilih untuk bermain gadget yang mengasikkan untuk peserta didik di Sekolah Dasar. Tidak hanya itu, munculnya pandemi covid mengakibatkan anak lebih intensif dalam menggunakan gadget. Mulai dari pembelajaran berbasis online atau dikenal dengan pembelajaran daring.

Kemampuan peserta didik kelas V di Sekolah Dasar Negeri diharapkan dapat mampu membaca Al-Qur'an seperti apa yang tertera dalam RPP indikator pencapaian kompetensi yang mengharuskan peserta didik dapat menulis, membaca Al-Qur'an dan menunjukan hafalan. Oleh karena itu peserta didik diharapkan untuk mengikuti kegiatan yang berkaitan dengan Agama diluar jam sekolah, seperti mengikuti TPA ataupun menundang guru les Agama, terutama peserta didik untuk mampu membaca Al-Quran.

Taman Pendidikan Al Qur'an (TPA) merupakan salah satu pendidikan non formal yang pengelolaanya diasuh oleh Kyai, Ustadz dan Ustadzah, dengan model pembelajaran yang tidak terpengaruh oleh Kurikulum sekolah formal. Pendidikan di Taman Pendidikan Al Qur'an (TPA) mengajarkan cara membaca kitab suci Al Qur'an dengan baik dan benar, pemahaman syariah Agama Islam seperti pelajaran Fiqih, Tajwid, Akhlak, Tarikh (Sejarah Islam) dengan mengedepankan pendidikan moral akhlakul karimah.

Intensitas pengunakan Gadget peserta didik kelas atas berpeluang cukup banyak yang berpengaruh untuk peserta didik tidak mengikuti kegiatan TPA dilingkungan rumahnya, sehingga mengeser minat peserta didik dalam belajar membaca Al-Qur'an. Ada peserta didik yang belajar membaca Al-Qur'an hanya disekolah saja. Dari hasil wawancara salah satu wali murid, waktu luang yang ada yang bisa digunakan untuk lebih banyak belajar membaca Al-Qur'an lebih jarang dilakukan, mereka lebih asik dengan Gadget.

Berdasarkan latar belakang diatas maka penulis tertarik untukmelakukan penelitian tindakan dengan judul: "Pengaruh Intensitas Penggunaan Gadget dan Keikutsertaan TPD terhadap Kemampuan Membaca Al-Quran Peserta Didik SD Negeri Gugus II Ahmad Yani Kecamatan Laweyan Surakarta Tahun Ajaran 2020/2021”

Berdasarkan analisis uraian dalam latar belakang di atas, maka dapat dikemukakan rumusan masalah sebagai berikut: (1) Bagaimana pengaruh intensitas penggunaan gadget terhadap kemampuan membaca Al-Quran peserta didik SD Negeri Gugus II Ahmad Yani Laweyan Surakarta tahun ajaran 2020/2021?, (2) Bagaimana pengaruh keikutsertaan TPA terhadap kemampuan membaca Al-Quran peserta didik SD Negeri Gugus II Ahmad Yani Laweyan Surakarta tahun ajaran 2020/2021?, (3) Bagaimana pengaruh intensitas penggunaan gadget dan keikutsertaan TPA terhadap kemampuan membaca Al-Quran 
peserta didik SD Negeri Gugus II Ahmad Yani Laweyan Surakarta tahun ajaran $2020 / 2021 ?$

\section{TINJAUAN PUSTAKA}

Sejak diumumkan pemerintah mengenai kasus pertama Coronavirus Disease 2019 (Covid-19) pada bulan Maret 2020 yang lalu, Indonesia kemudian dihadapkan pada masa pandemi. Hampir seluruh sektor kehidupan terdampak, tidak terkecuali di sektor pendidikan. Covid-19 ini menular begitu cepat dan telah menyebar hampir ke semua negara, termasuk Indonesia, sehingga Badan Kesehatan Dunia (WHO) menjadikan wabah ini sebagai pandemi global pada tanggal 11 Maret 2020 (Asmuni 2020). Di sektor pendidikan, pemerintah melalui Kementerian Pendidikan dan Kebudayaan (Kemdikbud) telah menerapkan kebijakan learning from home atau belajar dari rumah (BDR)/pembelajaran jarak jauh (PJJ). Undang-undang No. 20 tahun 2003 pasal 1 ayat 15, dijelaskan bahwa PJJ adalah pendidikan yang peserta didiknya terpisah dari pendidik dan pembelajarannya menggunakan berbagai sumber belajar melalui teknologi komunikasi, informasi dan media lain. Dalam pelaksanaannya, PJJ dibagi menjadi dua pendekatan, yaitu pembelajaran jarak jauh dalam jaringan (daring) dan pembelajaran jarak jauh luar jaringan (luring). Dalam pelaksanaan PJJ, satuan pendidikan dapat memilih pendekatan (daring atau luring atau kombinasi keduanya) sesuai dengan karakteristik dan ketersediaan, kesiapan sarana dan prasarana (Asmuni 2020).

Gadget adalah sebuah perangkat atau instrumen elektronik yang memiliki tujuan dan fungsi praktis terutama untuk membantu pekerjaan manusia. Perangkat elektronik kecil yang memiliki fungsi khusus. Diantaranya smratphone seperti iphone dan blackbaberry, serta notebook (perpaduan antara komputer portabel seperti notebook dan internet) (Widiawati, I, Sugiman 2014). Gadget yang saat ini banyak digemari masyarakat termasuk anak anak, mempunyai beberapa jenis jenis gadget yang sering digunakan (Irawan 2013). Telepon genggam, telepon seluler atau handphone adalah perangkat telekomunikasi elektronik yang mempunyai kemampuan dasar yang sama dengan telepon konvensional saluran tetap, namun dapat dibawa ke mana-mana (portabel atau mobile) dan tidak perlu disambungkan dengan jaringan telepon menggunakan kabel (nirkabel wireless) (Aziz 2016).

Taman pendidikan Al-Qur'an (TPA) merupakan salah satu cabang atau bagian dari Pendidikan yang ada didalam agama Islam. Sedangkan Pengertian Taman Pendidikan AlQur'an (TPA) sendiri adalah suatu lembaga pendidikan dan pengajaran Islam untuk anak 7 
sampai 12 tahun, untuk menjadikan anak mampu membaca Al-Qur'an dengan benar sesuai dengan target pokoknya (Chairani and Subandi 2010). Taman Pendidikan AlQur'an (TPA), pendidikan untuk baca dan menulis Al-Quran di kalangan anak-anak dan suatu lembaga pendidikan Islam masuk dalam jenis lembaga non formal, dimana lembaga tersebut sangat membatu anak dalam proses pembelajaran membaca Al-Qur'an secara fasih, benar yang sesuai dengan kaidah-kaidah atau aturan-aturan yang berlaku di dalam cara membaca Al-Qur'an dan tidak dilupakan setelah bisa anak bisa mengamalkan dalam kehidupan sehari-hari.

Kemampuan membaca Al-Quran dengan baik dan benar merupakan tujuan pokok dan perdana yang harus dicapai dan sekaligus dimiliki oleh setiap peserta santri. Pada saat pelaksanaan penerimaan anak setiap lembaga pendidikan islam, kemampuan membaca AlQuran hendaknya dijadikan sebagai materi pertama dan utama, sedang materi-materi yang lain sebagai penunjang. Materi penunjang juga penting, namun prioritas kedua setelah membaca Al-Quran, sedangkan materi-materi penunjang baru diberikan setelah para santri masuk ke program lanjutan. Dalam arti, materi penunjang tersebut sebagai pendukung atau sebagai tambahan saja setelah materi membaca Al-Quran tersebut (Mansur 2011).

\section{METODE}

Jenis penelitiannya adalah komparasi atau perbandingan. Desain penelitian kuantitatif kooperatif dengan analisis ANOVA dua jalur. Populasi dalam penelitian ini adalah peserta didik Kelas V SD Negeri Gugus II Ahmad Yani Laweyan Surakarta. Teknik sampling yang digunakan dalam penelitian ini adalah probability sampling. Teknik yang dipakai adalah teknik propotional rondom sampling. Teknik pengumpulan data menggunakan penelitian kepustakaan (library research) dan penelitian lapangan (field research) dengan metode angket (kuesioner) dan tes.

\section{HASIL PEMBAHASAN}

\section{Hasil Penelitian}

\section{Deskripsi Intensitas Penggunaan Gadget}

Hasil dari angket Intensitas Penggunaan Gadget

Jumlah frekuensi kemampuan siswa yang dikelompokkan berdasarkan rata-rata menjadi kelompok intensitas penggunaan gadget tinggi dan rendah sebagaimana dalam tabel berikut. 
Tabel 4.1 Kelompok Kemampuan Guru yang Kaitannya Intensitas Penggunaan Gadget

\begin{tabular}{|l|c|l|}
\hline \multicolumn{1}{|c|}{ Kelompok } & Frekuensi & \multicolumn{1}{|c|}{ Prosentase } \\
\hline Intensitas Penggunaan Gadget Tinggi & 13 & $25 \%$ \\
\hline Intensitas Penggunaan Gadget Rendah & 38 & $75 \%$ \\
\hline Jumlah & 51 & $100 \%$ \\
\hline
\end{tabular}

Berdasarkan tabel 4.4 menunjukkan bahwa 13 peserta didik yang memiliki intensitas penggunaan gadget tinggi sebanyak 25\% dari 51 peserta didik. Dan sebanyak 38 peserta didik memiliki intensitas penggunaan gadget rendah sebanyak $75 \%$ dari 51 peserta didik.

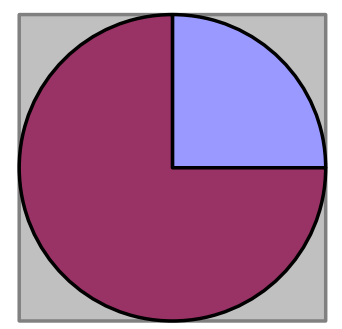

$\square$ Intensitas Penggunaan

Gadget Tinggi 25\%

$\square$ Intensitas Penggunaan

Gadget Rendah $75 \%$

Gambar 4.1 Kelompok Kemampuan Guru yang Kaitannya Intensitas Penggunaan Gadget

\section{Deskripsi Keikutsertaan TPA}

Hasil dari angket Keikutsertaan TPA

Tabel 4.2 Data Keikutsertaan TPA

\begin{tabular}{|c|l|c|c|}
\hline No & \multicolumn{1}{|c|}{ Keterangan } & Jumlah responden & Prosentase \\
\hline 1 & Mengikuti kegiatan TPA & 41 & $80,39 \%$ \\
\hline 2 & Tidak mengikuti kegiatan TPA & 10 & $19,6 \%$ \\
\hline
\end{tabular}

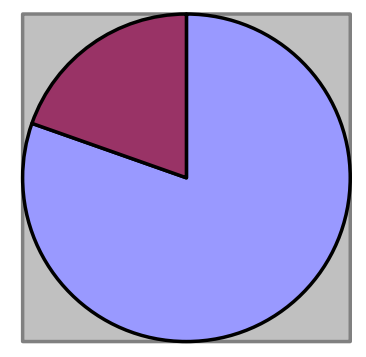

$\square$ Mengikuti TPA

$\square$ Tidak Mengikuti TPA

Gambar 4.2 Frekuensi Keikutsertaan TPA 
Dari hasil perolehan data angket keikutsertaan TPA menunjukkan bahwa mayoritas responden di SD Negeri Gugus II Ahmad Yani Laweyan Surakarta kelas V sebanyak 80,39\% (41 responden) mengikuti TPA dan minoritas responden sebanyak 19,6\% (10 responden) tidak mengikuti TPA.

\section{Hasil dari angket Kemampuan Membaca Al-Qur'an}

Jumlah responden peserta didik Kelas V SD Negeri Gugus II Ahmad Yani Laweyan Surakarta ada 51 reponden. Dari hasil pengambilan data kemampuan siswa membaca Al-Qur'an berdasarkan intensitas penggunaann gadget dan dan keikutsertaan TPA adalah sebagai berikut.

Tabel 4.3 Kemampuan Siswa Membaca Al-Qur'an Berdasarkan Intensitas Penggunaann Gadget dan Keikutsertaan TPA

\begin{tabular}{|c|c|c|c|}
\hline $\begin{array}{c}\text { Kemampuan Siswa Membaca Al- } \\
\text { Qur'an }\end{array}$ & Mengikuti TPA & $\begin{array}{c}\text { Tidak Mengikuti } \\
\text { TPA }\end{array}$ & Jumlah \\
\hline Intensitas Penggunaan Gadget Tinggi & $\begin{array}{c}83,88,87,88,87, \\
90,90,90,87,87, \\
83\end{array}$ & 61,63 & \multirow[t]{2}{*}{13} \\
\hline Total & 11 & 2 & \\
\hline $\begin{array}{c}\text { Intensitas Penggunaan Gadget } \\
\text { Rendah }\end{array}$ & $\begin{array}{l}87,87,92,91,92, \\
93,89,91,92,93, \\
87,87,85,87,87, \\
91,9093,87,87, \\
85,87,87,87,87, \\
91,88,91,92,91, \\
91,87,91,87,87, \\
61,63,57,58,52, \\
58,56,58,64,65\end{array}$ & $\begin{array}{l}57,58,52,58 \\
56,58,64,65\end{array}$ & 38 \\
\hline Total & 30 & 8 & 51 \\
\hline
\end{tabular}

Dari tabel 4.3 menjelaskan bahwa data kemampuan siswa membaca Al-Qur'an kaitannya dengan keikutsertaan TPA dan intensitas penggunaan gadget dibagi menjadi dua kategori kelompok intensitas penggunaan gadget tinggi dan intensitas penggunaan 
gadget rendah. Kelompok intensitas penggunaan gadget tinggi yang mengikuti TPA sebanyak 11 responden memiliki mean (rata-rata) sebanyak 87. Kelompok intensitas penggunaan gadget tinggi yang tidak mengikuti TPA sebanyak 2 responden memiliki mean (rata-rata) sebanyak 62. Kelompok intensitas penggunaan gadget rendah yang mengikuti TPA sebanyak 30 responden memiliki mean (rata-rata) sebanyak 89. Kelompok intensitas penggunaan gadget rendah yang tidak mengikuti TPA sebanyak 8 responden memiliki mean (rata-rata) sebanyak 59 seperti tabel di atas.

\section{Pengujian Persyaratan Analisis}

\section{a. Uji Normalitas}

Sebelum dilakukan uji hipotesis maka diisyaratkan dilakukan uji asumsi atau uji prasyarat. Salah satu uji prasyarat itu adalah uji normalitas. Tujuan uji normalitas ini adalah untuk mengetahui apakah data yang diperoleh berdistribusi normal atau tidak. Dalam penelitian ini untuk menguji normalitas data digunakan uji Shapiro Wilk dengan bantuan perangkat lunak SPSS 22 Windows. Dengan ukuran pengambilan kesimpulan adalah apabila hasil perhitungan diperoleh nilai Sig lebih besar dari 0,05 maka disimpulkan data distribusi normal, sedangkan apabila hasil perhitungan diperoleh nilai Sig kurang dari 0,05 maka disimpulkan data distribusi tidak normal. Hasil selengkapnya dapat dilihat pada tabel 4.4 berikut.

Tabel 4.4

Rangkuman Uji Normalitas

\begin{tabular}{|c|c|c|c|c|c|}
\hline \multirow[b]{2}{*}{ No } & \multirow[b]{2}{*}{ Kelompok } & \multirow[b]{2}{*}{$\mathrm{N}$} & \multicolumn{2}{|l|}{ Harga } & \multirow[b]{2}{*}{ Kesimpulan } \\
\hline & & & Sig & $\begin{array}{l}\text { Ukuran } \\
>0,05\end{array}$ & \\
\hline 1. & $\begin{array}{l}\text { Kemampuan Membaca } \\
\text { Al-Qur'an Peserta Didik }\end{array}$ & 51 & 0,025 & 0,05 & $\begin{array}{l}\text { Tidak } \\
\text { norma }\end{array}$ \\
\hline 2. & $\begin{array}{l}\text { Intensitas Penggunaan } \\
\text { Gadget }\end{array}$ & 51 & 0,373 & 0,05 & Normal \\
\hline
\end{tabular}

\section{b. Uji Homogenitas}

Berikut adalah hasil pengolahan data dengan SPSS untuk menguji homogenitas data dengan uji Levene. 
Tabel 4.5 Homogenitas Varian

\section{Levene's Test of Equality of Error Variances ${ }^{a}$}

Dependent Variable: Kemampuan Membaca Al-

Qur'an

\begin{tabular}{|l|l|l|l|}
\hline F & df1 & df2 & Sig. \\
\hline 1.606 & 3 & 47 & .201 \\
\hline
\end{tabular}

Tests the null hypothesis that the error variance of the dependent variable is equal across groups.

a. Design: Intercept + Intensitas + Keikutsertaan

+ Intensitas * Keikutsertaan

Dari tabel 4.5 menunjukkan bahwa signifikansi data homogenitas varian intensitas penggunaan gadget dan keikutsertaan TPA dari variable terikat kemampuan peserta didik membaca Al-Qur'an diperoleh nilai Sig. 0,201 > dari 0,05. Jadi dapat ditarik kesimpulan bahwa seluruh data varian dari variable terikat kemampuan peserta didik membaca Al-Qur'an dipengaruhi oleh intensitas penggunaan gadget dan keikutsertaan TPA dikatakan homogen.

\section{Pembahasan}

Setelah data dilakukan pengujian normalitas dan homogenitas data dan diketahui bahwa kemampuan membaca Al-Qur'sn siswa berdistribusi normal dan homogen maka dilanjutkan dengan uji hipotesis. Uji hipotesis digunakan untuk Uji statistic diperlukan untuk menjawab tentang perbedaan kemampuan membaca Al-Quran antara yang mengunakan gadget secara intensitas tinggi dengan mengunakan gadget secara intensitas rendah, dan juga adakah perbedaan kemampuan membaca Al-Quran antara yang mengikuti TPA dengan yang tidak mengikuti TPA.

Uji hipotesis dalam penelitian ini mengunakan iji Anava 2 Jalur. Tehnik Analisis of Varians (ANAVA) atau ANOVA dua jalan (Two Way ANOVA) yaitu satu jalur yang setiap perlakuannya dibagi menjadi beberapa kategori karena dua jalan mempertimbangkan dua factor yang mengakibatkan terjadinya penyimpangan (dispresi) dan nilai-nilai yang dihitung dalam standar deviasi atau varians (Sudjana 2000). Adapun hasil pengolajan data menunjukkan sebagai berikut. 
Tabel 4.6

Hasil Anova Dua Jalan

Tests of Between-Subjects Effects

Dependent Variable: Kemampuan Membaca Al-Qur'an

\begin{tabular}{|l|r|r|r|r|r|}
\hline Source & $\begin{array}{r}\text { Type III Sum } \\
\text { of Squares }\end{array}$ & df & \multicolumn{1}{c|}{$\begin{array}{c}\text { Mean } \\
\text { Square }\end{array}$} & \multicolumn{1}{c|}{ F } & Sig. \\
\hline Corrected Model & $7139.175^{\text {a }}$ & 3 & 2379.725 & 312.729 & .000 \\
Intercept & 117920.788 & 1 & 117920.788 & 15496.437 & .000 \\
Intensitas & 2.277 & 1 & 2.277 & .299 & .587 \\
Keikutsertaan & 4221.423 & 1 & 4221.423 & 554.754 & .000 \\
Intensitas * Keikutsertaan & 43.272 & 1 & 43.272 & 5.686 & .021 \\
Error & 357.648 & 47 & 7.610 & & \\
Total & 359334.000 & 51 & & & \\
Corrected Total & 7496.824 & 50 & & & \\
\hline
\end{tabular}

a. R Squared $=, 952$ (Adjusted R Squared $=, 949)$

1. Pengaruh intensitas penggunaan gadget terhadap kemampuan membaca Al-Quran peserta didik SD Negeri Gugus II Ahmad Yani Laweyan Surakarta tahun ajaran 2020/2021

Hipotesis yang diajukan adalah untuk mengetahui pengaruh intensitas penggunaan gadget terhadap kemampuan membaca Al-Quran peserta didik SD Negeri Gugus II Ahmad Yani Laweyan Surakarta tahun ajaran 2020/2021.

Ha : Ada pengaruh intensitas penggunaan gadget terhadap kemampuan membaca Al-Quran peserta didik SD Negeri Gugus II Ahmad Yani Laweyan Surakarta tahun ajaran 2020/2021

Ho : Tidak ada pengaruh intensitas penggunaan gadget terhadap kemampuan membaca Al-Quran peserta didik SD Negeri Gugus II Ahmad Yani Laweyan Surakarta tahun ajaran 2020/2021

Hipotesis tersebut diuji dengan bantuan perangkat SPSS 22 Windows dengan hasil sebagai berikut. 
Tabel 4.7

Hasil Anova Variable Intensitas Penggunaan Gadget

\begin{tabular}{|l|r|r|r|r|r|}
\hline Source & $\begin{array}{r}\text { Type III } \\
\text { Sum of } \\
\text { Squares }\end{array}$ & df & $\begin{array}{c}\text { Mean } \\
\text { Square }\end{array}$ & F & Sig. \\
& 2.277 & 1 & 2.277 & .299 & .587 \\
\hline Intensitas & & 1 & & \\
\hline
\end{tabular}

Berdasarkan tabel 4.7 menunjukkan bahwa intensitas penggunaan gadget nilai Sig.nya 0,587 > 0,05 maka Ho diterima dan Hipotesis alternative (Ha) ditolak. Artinya kemampuan membaca Al-Qur'an ditinjau dari intensitas penggunaan gadget, tidak ada pengaruh intensitas penggunaan gadget terhadap kemampuan membaca AlQuran peserta didik SD Negeri Gugus II Ahmad Yani Laweyan Surakarta tahun ajaran 2020/2021.

2. Pengaruh keikutsertaan TPA terhadap kemampuan membaca Al-Quran peserta didik SD Negeri Gugus II Ahmad Yani Laweyan Surakarta tahun ajaran 2020/2021.

Hipotesis yang diajukan adalah untuk mengetahui pengaruh keikutsertaan TPA terhadap kemampuan membaca Al-Quran peserta didik SD Negeri Gugus II Ahmad Yani Laweyan Surakarta tahun ajaran 2020/2021.

Ha : Ada pengaruh keikutsertaan TPA terhadap kemampuan membaca Al-Quran peserta didik SD Negeri Gugus II Ahmad Yani Laweyan Surakarta tahun ajaran 2020/2021.

Ho : Tidak pengaruh keikutsertaan TPA terhadap kemampuan membaca AlQuran peserta didik SD Negeri Gugus II Ahmad Yani Laweyan Surakarta tahun ajaran 2020/2021.

Tabel 4.8 Hasil Uji Anova Keikutsertaan TPA

\begin{tabular}{|l|c|r|r|r|r|}
\hline Source & Type III & df & Mean & F & Sig. \\
& $\begin{array}{l}\text { Sum of } \\
\text { Squares }\end{array}$ & & Square & & \\
& & & & & \\
\hline Keikutsertaan & 4221.423 & 1 & 4221.423 & 554.754 & .000 \\
\hline
\end{tabular}


Berdasarkan tabel 4.8 menunjukkan bahwa keikutsertaan TPA gadget nilai Sig.nya 0,00<0,05 maka Hipotesis alternative (Ha) diterima dan Ho ditolak. Artinya kemampuan membaca Al-Qur'an ditinjau dari keikutsertaan TPA, ada pengaruh keikutsertaan TPA terhadap kemampuan membaca Al-Quran peserta didik SD Negeri Gugus II Ahmad Yani Laweyan Surakarta tahun ajaran 2020/2021.

3. Pengaruh intensitas penggunaan gadget dan keikutsertaan TPA terhadap kemampuan membaca Al-Quran peserta didik SD Negeri Gugus II Ahmad Yani Laweyan Surakarta tahun ajaran 2020/2021.

Hipotesis yang diajukan adalah untuk mengetahui pengaruh intensitas penggunaan gadget dan keikutsertaan TPA terhadap kemampuan membaca Al-Quran peserta didik SD Negeri Gugus II Ahmad Yani Laweyan Surakarta tahun ajaran 2020/2021.

Ha : Ada pengaruh intensitas penggunaan gadget dan keikutsertaan TPA terhadap kemampuan membaca Al-Quran peserta didik SD Negeri Gugus II Ahmad Yani Laweyan Surakarta tahun ajaran 2020/2021.

Ho : Tidak pengaruh intensitas penggunaan gadget dan keikutsertaan TPA terhadap kemampuan membaca Al-Quran peserta didik SD Negeri Gugus II Ahmad Yani Laweyan Surakarta tahun ajaran 2020/2021.

Tabel 4.9 Hasil Uji Anova Pengaruh Intensitas Penggunaan Gadget dan Keikutsertaan TPA

\begin{tabular}{|c|c|c|c|c|c|}
\hline Source & $\begin{array}{l}\text { Type III Sum } \\
\text { of Squares }\end{array}$ & Df & $\begin{array}{l}\text { Mean } \\
\text { Square }\end{array}$ & $\mathrm{F}$ & Sig. \\
\hline $\begin{array}{l}\text { Intensitas } \\
\text { Keikutsertaan }\end{array}$ & 43.272 & 1 & 43.272 & 5.686 & .021 \\
\hline
\end{tabular}

Berdasarkan tabel 4.9 menunjukkan bahwa intensitas penggunaan gadget dan keikutsertaan TPA gadget nilai Sig.nya 0,021 < 0,05 maka Hipotesis alternative (Ha) diterima dan Ho ditolak. Artinya kemampuan membaca Al-Qur'an ditinjau dari intensitas penggunaan gadget dan keikutsertaan TPA, ada pengaruh intensitas penggunaan gadget dan keikutsertaan TPA terhadap kemampuan membaca Al-Quran peserta didik SD Negeri Gugus II Ahmad Yani Laweyan Surakarta tahun ajaran 2020/2021. 
Tabel 4.10 Rangkuman Pembahasan tiap varibel

\section{Intensitas Penggunaan Gadget}

Dependent Variable: Kemampuan Membaca Al-Qur'an

\begin{tabular}{|c|c|c|c|c|}
\hline \multirow[t]{2}{*}{ Intensitas Penggunaan Gadget } & \multirow[t]{2}{*}{ Mean } & \multirow[t]{2}{*}{$\begin{array}{l}\text { Std. } \\
\text { Error }\end{array}$} & \multicolumn{2}{|c|}{$\begin{array}{c}\text { 95\% Confidence } \\
\text { Interval }\end{array}$} \\
\hline & & & $\begin{array}{l}\text { Lower } \\
\text { Bound }\end{array}$ & $\begin{array}{l}\text { Upper } \\
\text { Bound }\end{array}$ \\
\hline Intensitas Penggunaan Gadget Tinggi & 74.636 & 1.060 & 72.503 & 76.769 \\
\hline Intensitas Penggunaan Gadget Rendah & 73.983 & .549 & 72.879 & 75.087 \\
\hline
\end{tabular}

\section{Keikutsertaan TPA}

Dependent Variable: Kemampuan Membaca Al-Qur'an

\begin{tabular}{|l|r|r|r|r|}
\hline Keikutsertaan TPA & Mean & \multicolumn{1}{c|}{$\begin{array}{c}\text { Std. } \\
\text { nnnyy }\end{array}$} & & \multicolumn{2}{|c|}{$95 \%$ Confidence Interval } \\
\cline { 4 - 5 } & & Error & Lower Bound & Upper Bound \\
\hline Mengikuti TPA & 88.370 & .486 & 87.392 & 89.348 \\
Tidak Mengikuti TPA & 60.250 & 1.090 & 58.056 & 62.444 \\
\hline
\end{tabular}




\section{Intensitas Penggunaan Gadget * Keikutsertaan TPA}

Dependent Variable: Kemampuan Membaca Al-Qur'an

\begin{tabular}{|c|c|c|c|c|c|}
\hline \multirow[t]{2}{*}{ Intensitas Penggunaan Gadget } & \multirow[t]{2}{*}{ Keikutsertaan TPA } & \multirow[t]{2}{*}{ Mean } & \multirow[t]{2}{*}{$\begin{array}{l}\text { Std. } \\
\text { Error }\end{array}$} & \multicolumn{2}{|c|}{$\begin{array}{l}\text { 95\% Confidence } \\
\text { Interval }\end{array}$} \\
\hline & & & & $\begin{array}{l}\text { Lower } \\
\text { Bound }\end{array}$ & $\begin{array}{l}\text { Upper } \\
\text { Bound }\end{array}$ \\
\hline $\begin{array}{l}\text { Intensitas Penggunaan Gadget } \\
\text { Tinggi }\end{array}$ & $\begin{array}{l}\text { Mengikuti TPA } \\
\text { Tidak Mengikuti } \\
\text { TPA }\end{array}$ & $\begin{array}{l}87.273 \\
62.000\end{array}$ & $\begin{array}{r}.832 \\
1.951\end{array}$ & $\begin{array}{l}85.600 \\
58.076\end{array}$ & $\begin{array}{l}88.946 \\
65.924\end{array}$ \\
\hline $\begin{array}{l}\text { Intensitas Penggunaan Gadget } \\
\text { Rendah }\end{array}$ & $\begin{array}{l}\text { Mengikuti TPA } \\
\text { Tidak Mengikuti } \\
\text { TPA }\end{array}$ & $\begin{array}{l}89.467 \\
58.500\end{array}$ & .504 & $\begin{array}{l}88.453 \\
56.538\end{array}$ & $\begin{array}{l}90.480 \\
60.462\end{array}$ \\
\hline
\end{tabular}

Berdasarkan hasil penelitian pada Tabel 4.10 diketahui bahwa.

a. Intensitas penggunaan gadget berpengaruh terhadap kemampuan membaca Al-Quran peserta didik. Hal ini ditunjukkan dengan nilai rata-rata yang memiliki sedikit perbedaan nilai rata-rata kemampuan membaca Al-Qur'an dengan intensitas penggunaan gadget tinggi 74,636 sedangkan dengan intensitas penggunaan gadget rendah 73,983. Karena perbedaan sangat tipis sehingga tinggi rendahnya intensitas penggunaan gadget memiliki pengaruh terhadap kemampuan membaca Al-Quran peserta didik.

Penelitian di atas berkaitan dengan penelitian (Azzahra 2019) hasil dari penelitian yang dilakukan menunjukkan bahwa intensitas penggunaan gadget berpengaruh terhadap interaksi sosial. Nilai dari R Squares sebesar 0,068 atau 6,8\% dan sisanya dipengaruhi oleh variabel lain sebesar 0,932 atau 93,2 \%. Berdasarkan hasil analisa regresi dapat dilihat apabila semakin rendah intensitas penggunaan gadget maka akan semakin tinggi interaksi sosial, sehingga dapat dibuktikan bahwa ada pengaruh antara intensitas penggunaan gadget terhadap interaksi sosial pada mahasiswa. Penelitian (Tanjung, Huriyati, and Ismail 2017) juga meneliti mengenai gadget. Hasil penelitian menunjukkan bahwa anak prasekolah dengan intensitas penggunaan gadget yang tinggi berisiko 1,3 kali lebih besar mengalami obesitas (p: 0,028, RP =1,25). Anak prasekolah dengan intensitas penggunaan gadget tinggi dan pendidikan ayah tinggi, perilaku 
sedentari tinggi, sosial ekonomi cukup, serta pola makan tidak baik berisiko 2,1 kali lebih besar mengalami obesitas.

Selain itu penelitian (Nurmasari, 2016) dari hasil analisis diperoleh nilai p 0,000 dan koefisien korelasi 0,346. Hal ini menunjukkan $\mathrm{p}<0,05$ yang berarti terdapat hubungan yang signifikan antara intensitas penggunaan gadget dengan keterlambatan perkembangan pada aspek bicara dan bahasa pada balita dan memiliki kekuatan hubungan yang lemah $(0,20<\mathrm{KK}<0,40)$. Penelitian (Istiqomah, 2011) menunjukan bahwa ada hubungan yang positif dansignifikan antara intensitas penggunaan gadget dengan hasil belajar dengan nilai $r$ hitung 0,405 pada taraf signifikansi $0,00<0,05$, ada hubungan yang positif dan signifikan antara motivasi belajar dan hasil belajar siswa dengan nilai $\mathbf{r}_{\text {hitung }} 0,300$ pada taraf signifikansi $0,00<0,05$, serta ada hubungan positif dan signifikan antara intensitas penggunaan gadget dan motivasi belajar dengan hasil belajar muatan Ilmu Pengetahuan Sosial dengan $r$ hitung 0,469 pada taraf signifikansi $0,00<0,05$. Kontribusi variabel bebas intensitas penggunaan gadget dan motivasi belajar dengan hasil belajar muatan pembelajaran IPS sebesar 21,3\%.

b. Keikutsertaan TPA berpengaruh terhadap kemampuan membaca Al-Quran. Hal ini ditunjukkan dengan adanya perbedaan yang signifikan nilai rata rata peserta yang mengkiti TPA 88,37 sedangkan yang tidak mengikuti TPA 60,25 ini menandakan bahwa keikutsertaan TPA berpengaruh terhadap kemampuan membaca Al-Quran peserta didik SD Negeri Gugus II Ahmad Yani Laweyan Surakarta tahun ajaran 2020/2021.

Keberadaan pendidikan al-Qur'an tersebut membawa misi yang sangat mendasar terkait dengan pentingnya memperkenalkan dan menanamkan nilai-nilai al-Qur'an sejak usia dini (Malik 2013). TPA sebagai lembaga dasar untuk belajar Al Qur'an harus memberikan layanan dan kualitas berstandar nasional, agar mampu mencetak peserta didik/santri yang cerdas dan professional di bidang Al-Qur'an sehingga bisa mengatasi krisis moral yang tengah melanda negeri ini (Priyadi, Hidayat, and Islamawati 2013). Penelitian serupa dilakukan oleh (Nurjayanti, Pudyaningtyas, and Dewi 2020) yang menjelaskan bahwa program TPA Rusunawa Jurug menggunakan kurikulum yang mengacu pada pedoman dari kementerian agama dengan ditambahi mutatan lokal rusunawa Jurug. Kegiatan pengelolaan meliputi perencanaan, pelaksanaan, dan evaluasi terhadap administrasi, pembelajaran, dan pendanaan. Kegiatan pembelajaran TPA dilaksanakan pada hari Senin, Rabu, dan Jumat pada pukul 16.00-20.00. Program TPA dapat menstimulasi perkembangan anak usia dini melalui pembiasaan dan materi yang diajarkan di TPA. Faktor keberhasilan yang menentukan efektivitas pembelajaran di 
TPA Al-Hikmah dalam meningkatkan kemampuan membaca Al-Qur"an santri terletak pada kemampuan ustadz/ustadzah dalah mengefektifkan sistem assistensi, kontrol yang baik dalam sistem privat dengan tetap mengacu pada penerapan sistem modul dalam pengajaran iqra' sehingga hasil membaca Al-Qur'an santri mendapatkan hasil yang baik.

c. Intensitas penggunaan gadget dan keikutsertaan TPA berpengaruh terhadap kemampuan membaca Al-Quran. Hal ini ditunjukkan dengan adanya perbedaan yang signifikan nilai rata-rata intensitas penggunaan gadget tinggi dan mengikuti TPA 87,273, nilai rata-rata intensitas penggunaan gadget tinggi dan tidak mengikuti TPA 62, nilai rata-rata intensitas penggunaan gadget rendah dan mengikuti TPA 89,467 dan nilai rata-rata intensitas penggunaan gadget rendah dan tidak mengikuti TPA 58,5. Ini menunjukkan bahwa nilai rata-rata tertinggi adalah peserta didik yang memiliki intensitas penggunaan gadget rendah dan mengikuti TPA dan nilai yang terendah adalah peserta didik yang intensitas penggunaan gadget rendah dan tidak mengikuti TPA.

Pendapat tersebut diperkuat oleh penelitian (Windi 2009) yang menyatakan bahwa Kompetensi Dasar Pendidikan Agama Islam pada TPA, pada dasarnya tidak jauh berbeda Sekolah Dasar, yang berbeda hanya persiapan dan metode yang digunakan oleh guru dalam proses belajar mengajar. Pada sekolah dasar, guru menggunakan metode yang bersifat klasikal, karena terbatasnya waktu. Sedangkan, guru TPA menggunakan metode dengan memberikan perhatian dan pembelajaran pada tiap- tiap anak (individu) secara langsung, sehingga terlihat jelas bahwa pembelajaran pada TPA lebih optimal dan efektif dalam penyampaian materi pembelajarannya. Kemudian, mengenai hasil belajar terlihat dengan jelas perbedaan antara siswa yang mengikuti pendidikan pada TPA dengan siswa yang tidak mengikuti pendidikan di TPA. Perbedaan tersebut terjadi pada semua penilaian, baik kemampuan mereka dalam memahami materi pelajaran tentang baca-tulis al- Qur'an, kemampuan menulis al-Qur'an maupun kemampuan mereka dalam membaca al-Qur'an. Siswa yang mengikuti pendidikan pada TPA tentu lebih menguasai (unggul) kemampuannya dibandingkan dengan siswa yang tidak mengikuti pendidikan pada TPA. 


\section{KESIMPULAN}

Berdasarkan hasil analisis dan pembahasan dalam penelitian ini, dapat ditarik kesimpulan bahwa (1) Intensitas penggunaan gadget berpengaruh terhadap kemampuan membaca Al-Quran peserta didik. Hal ini ditunjukkan dengan nilai rata-rata yang memiliki sedikit perbedaan antara nilai rata-rata kemampuan membaca Al-Qur'an dengan intensitas penggunaan gadget tinggi 74,636 sedangkan dengan intensitas penggunaan gadget rendah 73,983. Meskipun perbedaan sangat tipis namun, intensitas penggunaan gadget berpengaruh terhadap kemampuan membaca Al-Quran peserta didik, (2) Keikutsertaan TPA berpengaruh terhadap kemampuan membaca Al-Quran. Hal ini ditunjukkan dengan adanya perbedaan yang signifikan nilai rata rata peserta yang mengkiti TPA 88,37 sedangkan yang tidak mengikuti TPA 60,25 ini menandakan bahwa keikutsertaan TPA berpengaruh terhadap kemampuan membaca Al-Quran peserta didik SD Negeri Gugus II Ahmad Yani Laweyan Surakarta tahun ajaran 2020/2021, dan Intensitas penggunaan gadget dan keikutsertaan TPA berpengaruh terhadap kemampuan membaca Al-Quran. Hal ini ditunjukkan dengan adanya perbedaan yang signifikan nilai rata-rata intensitas penggunaan gadget tinggi dan mengikuti TPA 87,273, nilai rata-rata intensitas penggunaan gadget tinggi dan tidak mengikuti TPA 62, nilai rata-rata intensitas penggunaan gadget rendah dan mengikuti TPA 89,467 dan nilai rata-rata intensitas penggunaan gadget rendah dan tidak mengikuti TPA 58,5. Ini menunjukkan bahwa nilai rata-rata tertinggi adalah peserta didik yang memiliki intensitas penggunaan gadget rendah dan mengikuti TPA dan nilai yang terendah adalah peserta didik yang intensitas penggunaan gadget rendah dan tidak mengikuti TPA. 


\section{DAFTAR PUSTAKA}

Asmuni, Asmuni. 2020. "Problematika Pembelajaran Daring Di Masa Pandemi Covid-19 Dan Solusi Pemecahannya." Jurnal Paedagogy $7 \quad$ (4): 281. https://doi.org/10.33394/jp.v7i4.2941.

Aziz, Abdul. 2016. "Handphone Mempengaruhi Terhadap Perilaku Remaja Usia SLTP (1315 Tahun) Di Dusun Tegalpare Kecamatan Muncar Kabupaten Banyuwangi." Darussalam: Jurnal Pendidikan VII (2): 123-48.

Azzahra, Fatimah. 2019. "Hubungan Antara Intensitas Penggunaan Gadget."

Chairani, Lisya, and M.A Subandi. 2010. "Psikologi Santri Penghafal Al-Qur'an (Peranan Regulasi Diri).” In . Yogyakarta: Pustaka Pelajar.

Irawan, J. 2013. Pengaruh Kegunaan Gadget Terhadap Kemampuan Bersosialisasi Pada Remaja. Fakultas Psikologi: Universitas Islam Riau.

Malik, Hatta Abdul. 2013. "Pemberdayaan Taman Pendidikan Al-Qur'an (TPQ) ALhusna Pasadena Semarang." Dimas: Jurnal Pemikiran Agama Untuk Pemberdayaan 13 (2): 387-404. http://www.journal.walisongo.ac.id/index.php/dimas/article/view/60.

Mansur. 2011. "Pendidikan Anak Usia Dini (PAUD)." In . Yogyakarta: Pustaka Pelajar.

Nurjayanti, Desi, Adriani Rahma Pudyaningtyas, and Nurul Kusuma Dewi. 2020. "PENERAPAN PROGRAM TAMAN PENDIDIKAN ALQURAN ( TPA ) UNTUK ANAK USIA DINI Program Studi PG-PAUD, Universitas Sebelas Maret Surakarta Harus Memiliki Lembaga Atau Organisasi Payung TPA Dan Dikepalai Oleh Kepala Unit Diwajibkan Memiliki Program Yang Jelas Yai." Jurnal Kumara Cendekia 8 (2): 183-96.

Priyadi, Unggul, Syarif Nur Hidayat, and Aprillia Islamawati. 2013. "Peningkatan Mutu Pembelajaran Taman Pendidikan Al-Qur'an Dengan Pembuatan Kurikulum TPA." Jurnal Inovasi Dan Kewirausahaan Seri Pengabdian Masyarakat 2 (3): 204-11.

Sudjana, D. 2000. "Strategi Pembelajaran Dalam Pendidikan Luar Sekolah.” In . Bandung: Nusantara Press.

Tanjung, Fajar Sri, Emy Huriyati, and Djauhar Ismail. 2017. "Intensitas Penggunaan Gadget Pada Anak Prasekolah Yang Kelebihan Berat Badan Di Yogyakarta (Intensity of Gadget Use among Overweight Preschool Children in Yogyakarta)." Berita Kedokteran Masyarakat Journal of Community Medicine and Public Health 33 (12): 603-8.

Widiawati, I, Sugiman, H \& Edy. 2014. "Pengaruh Penggunaan Gadget Terhadap Daya Kembang Anak." E-Journal Keperawatan 6: 1-6.

Windi. 2009. "Kontribusi Taman Pendidikan Al-Qur'an (TPA) Terhadap Pencapaian Kompetensi Pembelajaran Pendidikan Agama Islam Di Sekolah Dalam Hal Baca-Tulis Al-Qur'an: Studi Kasus Di SDN 02 Pondok Pucung, Kecamatan Pondok Aren, Kota Tangerang-Selatan, Propinsi Banten." 